\title{
SEBARAN FASILITAS PELAYANAN PUBLIK DAN PILIHAN MASYARAKAT DI KECAMATAN PONTIANAK UTARA, KOTA PONTIANAK
}

\author{
Yudi Purnomo \\ Program Studi Arsitektur Universitas Tanjungpura Pontianak \\ yudipurnomo@teknik.untan.ac.id
}

\section{Agustiah Wulandari}

Program Studi Perencanaan Wilayah dan Kota Universitas Tanjungpura Pontianak

agustiahwulandari@teknik.untan.ac.id

\begin{abstract}
Abstrak
Fasilitas pelayanan publik merupakan salah satu fungsi bangunan gedung yang menjadi tujuan masyarakat dalam berbagai urusan administrasi maupun pemerintahan di sebuah kota maupun daerah. Proses administrasi, dengan jenis dan hierarki yang beragam, yang dilakukan sering kali menuntut masyarakat untuk melakukan perjalanan dari tempat tinggal menuju fasilitas pelayanan publik dan sebaliknya. Jenis layanan publik dan jarak jangkau perjalanan dapat menjadi salah satu faktor yang menentukan sebaran dan alokasi fasilitas pelayanan publik dalam sebuah bagian wilayah kota.

Artikel ini ditulis dengan tujuan untuk menjelaskan pilihan (preferensi) masyarakat terhadap sebaran lokasi fasilitas pelayanan publik di Kota Pontianak, khususnya Kecamatan Pontianak Utara. Penelitian ini dilakukan dengan menjadikan jenis dan hierarki fasilitas pelayanan publik di Kota Pontianak, radius layanan, perilaku perjalanan, kepemilikan moda, dan lain-lain sebagai variabel penelitian. Selanjutnya artikel ini akan menggunakan pendekatan statistik deskriptif untuk memberikan gambaran pilihan masyarakat terhadap sebaran fasilitas pelayanan publik.

Terdapat dua faktor utama yang mempengaruhi pilihan masyarakat di Kecamatan Pontianak Utara terhadap sebaran fasilitas pelayanan publik, yaitu jarak tempuh dan kualitas layanan. Salah satu karakter perjalanan masyarakat di wilayah ini adalah perjalanan dengan jarak tempuh dalam rentang yang jauh tidak menjadi kendala untuk dilalui jika fasilitas yang akan dikunjungi adalah fasilitas rekreasi, perniagaan, dan peribadatan.
\end{abstract}

Kata-kata Kunci: fasilitas pelayanan publik, jarak tempuh, statistik deskriptif, Kota Pontianak

\section{DISTRIBUTION OF PUBLIC SERVICE FACILITIES AND COMMUNITY OPTIONS IN NORTH PONTIANAK DISTRICT, PONTIANAK}

\begin{abstract}
Public service facility is one of the places that the community goals in various purposes and administrative affairs in a city or region. The service processes, with diverse types and hierarchies, often require people to travel from residence to public service facilities and vice versa. The type of public service and travel distance can be one of the factors that determine the distribution and allocation of public service facilities in a part of the city area.

This article aims to explain the society's choice to the distribution of public service facilities in Pontianak City, especially Pontianak Utara Subdistrict. This research is done by making the type and hierarchy of public service facility in Pontianak City, service radius, travel behavior, and so on
\end{abstract}


as research variables. Furthermore, this article will use a descriptive statistical approach to provide an overview of society's choice of public service facilities.

There are two main factors influencing the choice of people in Pontianak Utara Subdistrict to the distribution of public service facilities, ie mileage and service quality. One character of the community's journeys in the region is long distance travel is not an obstacle to go through if the facilities to be visited are recreational facilities, trade facilities, and worship facilities.

Keywords: public service facilities, mileage, descriptive statistics, Pontianak City

\section{Pendahuluan}

Kecamatan Pontianak Utara merupakan kecamatan dengan wilayah terluas di Kota Pontianak. Wilayah ini juga memiliki jumlah penduduk terbesar kedua setelah Kecamatan Pontianak Barat. Walaupun demikian, dikarenakan wilayahnya yang paling luas menjadikan wilayah ini merupakan wilayah kecamatan dengan kepadatan penduduk terkecil dibandingkan dengan kecamatan lainnya di Kota Pontianak, yaitu $3.312 \mathrm{jiwa} / \mathrm{km}^{2}$. Sebaran penduduk belum merata di wilayah ini disebabkan kurangnya daya tarik wilayah ini di bandingkan wilayah lainnya yang relatif dekat dengan pusat Kota Pontianak.

Faktor geografis wilayah yang dipisahkan oleh Sungai Kapuas dan Sungai Landak (Lihat Gambar 1), menjadikan pencapaian ke wilayah ini relatif cukup jauh dari pusat kota. Ada dua alternatif pencapaian utama, yaitu melalui Jembatan Kapuas dan Jembatan Landak serta melalui penyeberangan/angkutan sungai. Kondisi tersebut menyebabkan sering padatnya jalan raya yang menghubungkan Kecamatan Pontianak Utara dengan pusat kota, karena kapasitas jalan yang tidak sebanding dengan volume akibat pergerakan yang terjadi.

Sebagai wilayah yang memiliki tingkat kepadatan terendah, tidak menjadikan wilayah ini memiliki sebaran fasilitas pelayanan publik yang rendah. Beberapa fasilitas pelayanan publik telah tersebar dengan berbagai tingkat dan hierarki pelayanan. Fasilitas pendidikan merupakan fasilitas yang dinilai cukup memadai di wilayah ini, namun beberapa fasilitas juga dirasakan masih terdapat kekurangan. Walaupun secara hierarki tersedia di wilayah kecamatan lainnya, namun karena hambatan aksesibilitas, khususnya jarak dan waktu tempuh, menjadikan sebaran fasilitas layanan publik dianggap tidak cukup merata. Lingkup layanan dalam struktur ruang kota dan administrasi perkotaan di Kecamatan Pontianak Utara dibagi empat wilayah sub pelayanan di tingkat kelurahan, yaitu Kelurahan Batu Layang, Kelurahan Siantan Hilir, Kelurahan Siantan Tengah, dan Kelurahan Siantan Hulu.

Pemerintah Kota Pontianak dalam memberikan pelayanan publik yang prima kepada masyarakat membutuhkan sarana dan prasarana yang memadai sesuai dengan fungsi pelayanan yang diberikan. Gedung kantor pelayanan publik merupakan fasilitas yang secara tidak langsung berfungsi menunjang terselenggaranya suatu proses pelayanan pemerintah kepada masyarakat dalam meningkatkan kinerja pelayanan sesuai dengan tugas dan tanggung jawab pelayanan. Sedangkan ruangan kantor dan perlengkapan kerja merupakan fasilitas yang secara langsung berfungsi sebagai penunjang proses penyelenggaraan pemerintahan kota dalam mencapai sasaran pelayanan yang ditetapkan (Penjelasan sarana dan prasarana kerja selanjutnya dapat dilihat dalam Peraturan Menteri Dalam Negeri Nomor 7 Tahun 2006 Tentang Standardisasi Sarana Dan Prasarana Kerja Pemerintahan Daerah).

Bangunan gedung kantor pelayanan publik merupakan salah satu sektor publik yang mendapat perhatian cukup besar karena menjadi bagian penting bagi kehidupan warga kota. Perilaku masyarakat sebagai pengguna yang semakin beragam, jenis layanan dan hierarki layanan akan menentukan karakter dan persyaratan penentuan lokasi dan perencanaan bangunan gedung kantor pelayanan publik. Pilihan-pilihan masyarakat terhadap fasilitas pelayanan publik menjadi penting 
untuk dipelajari sebagai dasar dalam pengambilan keputusan dalam menentukan sebaran dan hierarki pelayanan di masing-masing wilayah bagian kota.

Tulisan ini bertujuan untuk memberikan gambaran pilihan pelayanan publik masyarakat terhadap sebaran lokasi di Kecamatan Pontianak Utara. Tulisan ini disusun menggunakan pendekatan statistik deskriptif untuk memberikan gambaran perilaku masyarakat dalam memilih fasilitas pelayanan publik. Pendekatan teoretis tentang lokasi, pelayanan publik, perilaku pergerakan atau perjalanan menjadi dasar dalam menentukan variabel amatan. Adapun metode penelitian akan dijelaskan lebih lanjut dalam bagian isi tulisan ini.

\section{Kajian Pustaka Pelayanan publik}

Pelayanan publik adalah kegiatan atau rangkaian kegiatan dalam rangka pemenuhan kebutuhan pelayanan sesuai dengan peraturan perundang-undangan bagi setiap warga negara dan penduduk atas barang, jasa, dan/atau pelayanan administratif yang disediakan oleh penyelenggara pelayanan publik (Pemerintah Republik Indonesia, 2009). Penyelenggara pelayanan publik, yang selanjutnya disebut Penyelenggara, adalah setiap institusi penyelenggara negara, korporasi, lembaga independen yang dibentuk berdasarkan undang-undang untuk kegiatan pelayanan publik, dan badan hukum lain yang dibentuk semata-mata untuk kegiatan pelayanan publik. Ruang lingkup pelayanan publik meliputi pelayanan barang publik dan jasa publik serta pelayanan administratif, yang terdiri dari pendidikan, pengajaran, pekerjaan dan usaha, tempat tinggal, komunikasi dan informasi, lingkungan hidup, kesehatan, jaminan sosial, energi, perbankan, perhubungan, sumber daya alam, pariwisata, dan sektor strategis lainnya (Pemerintah Republik Indonesia, 2009).

Membicarakan manajemen pelayanan publik tidak terlepas dari bagaimana memahami ciri-ciri pelayanan publik. Sebagaimana organisasi perkotaan, pelayanan publik memiliki ciri-ciri sebagai berikut (Nurmandi, 1999):

- Tidak dapat memilih konsumen

- Peranannya dibatasi oleh peraturan perundang-undangan

- Politik menginstitusionalkan konflik

- Pertanggungjawaban yang kompleks

- Sangat sering diteliti

- Semua tindakan harus mendapatkan justifikasi

- Tujuan dan output sulit diukur atau ditentukan

Pelayanan publik pada sektor pemerintah menggunakan rambu-rambu yang diberikan oleh peraturan pemerintah pusat atau pemerintah daerah dan dapat menjadi sebuah ciri yang khas. Dalam manajemen pelayanan publik dikenal tiga aktor (Nurmandi, 1999), yaitu konsumen (service consumer), produsen (service producer) dan pengatur pelayanan (service arranger). Konsumen secara langsung menerima pelayanan dari produsen. Produsen dalam kaitan ini dapat berupa instansi pemerintah pusat maupun pemerintah daerah atau lembaga swasta. Sedangkan pengatur pelayanan adalah lembaga yang mengaur mekanisme antara penyedia pelayanan (produsen) dengan pihak yang menerima pelayanan (konsumen). Lembaga ini dapat berasal dari lembaga pemerintah ataupun Lembaga Swadaya Masyarakat (LSM). 


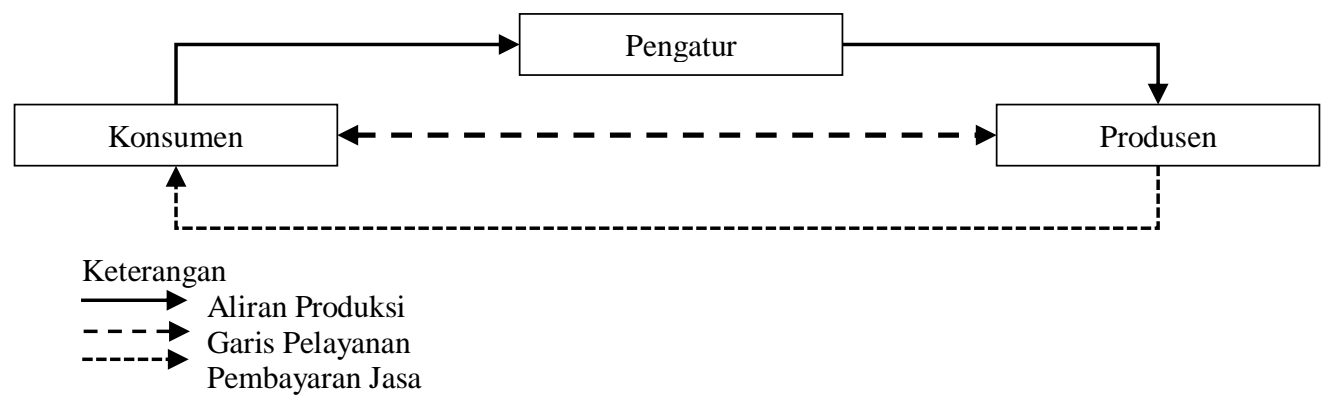

Gambar 1. Elemen Pelayanan Publik

Sumber: Nurmandi, 1999

\section{Teori Lokasi}

Teori lokasi adalah ilmu yang menyelidiki tata ruang (spatial order) kegiatan ekonomi, atau ilmu yang menyelidiki alokasi geografis dari sumber-sumber yang potensial, serta hubungannya dengan atau pengaruhnya terhadap keberadaan berbagai macam usaha/kegiatan lain baik ekonomi maupun sosial (Tarigan, 2006). Salah satu unsur ruang adalah jarak. Jarak dalam ruang akan menciptakan keterkaitan dengan waktu dan biaya yang diperlukan untuk mencapai suatu lokasi. Kejelasan informasi merupakan salah satu faktor yang dipengaruhi oleh faktor jarak, semakin jauh jarak suatu lokasi akan menyebabkan potensi dan karakter lokasi menjadi kurang diketahui.

Salah satu hal yang banyak dibahas dalam teori lokasi adalah pengaruh jarak terhadap intensitas orang bepergian dari satu lokasi ke lokasi lainnya. Terkait dengan lokasi maka salah satu faktor yang menentukan apakah suatu lokasi menarik untuk dikunjungi atau tidak adalah tingkat aksesibilitas (Tarigan, 2006). Tingkat aksesibilitas adalah tingkat kemudahan untuk mencapai suatu lokasi ditinjau dari lokasi lain di sekitarnya. Tingkat aksesibilitas antara lain dipengaruhi oleh jarak, kondisi prasarana perhubungan, ketersediaan berbagai sarana penghubung termasuk frekuensinya dan tingkat keamanan serta kenyamanan untuk melalui jalur tersebut.

\section{Ciri perjalanan}

Ciri perjalanan ditentukan oleh dua faktor, yaitu (Warpani, 1990):

1) Jarak perjalanan

Jarak perjalanan mempengaruhi orang dalam menentukan pilihan moda. Hal ini dapat diukur dengan tiga cara popular yaitu jarak fisik udara, jarak fisik yang di ukur sepanjang lintasan yang dilalui dan jarak yang diukur dengan waktu perjalanan.

2) Tujuan perjalanan

Pengalaman menunjukkan adanya keterkaitan antara jumlah pemakai angkutan umum dan tujuan perjalanan.

Selanjutnya ciri perjalanan juga dipengaruhi oleh beberapa kategori yang berkaitan dengan ciri sosial ekonomi sebagai berikut (Warpani, 1990):

1) Penghasilan

Penggunaan kendaraan untuk melakukan perjalanan bergantung pada kemampuan orang untuk membayar dan merawatnya.

2) Kemilikan kendaraan

Kemilikan kendaraan atau kesempatan menggunakan kendaraan mungkin merupakan faktor yang paling berpengaruh pada pemilihan moda angkutan.

3) Kerapatan permukiman

Telah terbukti apabila kepadatan bersih daerah permukiman menurun maka penggunaan kendaraan umum menurun pula. 
4) Faktor sosial ekonomi

Besarnya keluarga, struktur kelamin, usia anggota keluarga, proporsi angkatan kerja perempuan yang kawin, jenis kekayaan yang dimiliki dan jenis pekerjaan adalah sejumlah faktor yang mempengaruhi pemilihan moda angkutan.

\section{Faktor penentu Pemilihan Rute}

Faktor penentu utama pemilihan rute antara lain (Tamin, 2000):

1) Waktu tempuh waktu tempuh adalah waktu total perjalanan yang diperlukan, termasuk berhenti dan tundaan dari suatu tempat ke tempat lain melalui rute tertentu. waktu tempuh dapat diamati dengan dua cara. Pertama, dengan metode pengamat bergerak, yaitu pengamat mengemudikan kendaraan survei di dalam arus lalu lintas dan mencatat waktu tempuhnya.

2) Nilai waktu

Nilai waktu adalah nilai sejumlah uang yang disediakan seseorang untuk dikeluarkan (di hemat) untuk menghemat satu unit waktu perjalanan. Nilai waktu biasanya sebanding dengan pendapatan per kapita, merupakan perbandingan yang tetap dengan tingkat pendapatan. Ini di dasari atas asumsi bahwa waktu perjalanan tetap konstan sepanjang waktu. Relative terhadap pengeluaran konsumen. Ini merupakan asumsi yang agak berani karena sedikit atau tidak adanya data empiris yang menyokongnya.

3) Biaya perjalanan

Biaya perjalanan dapat dinyatakan dalam bentuk uang. Waktu tempuh, jarak atau kombinasi ketiganya yang biasa disebut dengan biaya gabungan. Dalam hal ini di asumsikan bahwa total biaya perjalanan sepanjang rute tertentu adalah jumlah dari biaya setiap ruas jalan yang di lalui. Jadi, dengan mengetahui semua biaya dari setiap ruas jalan. Dapat di tentukan (dengan algoritme tertentu) rute terbaik yang dapat di lalui pada jaringan jalan tersebut. Tetapi, persepsi setiap pengendara terhadap biaya perjalanan jelas berbeda-beda sehingga sukar menjabarkan perbedaan ke dalam bentuk model pemilihan rute yang sederhana.

4) Biaya operasi kendaraan

Biaya operasi kendaraan merupakan baya yang penting. Perbaikan atau peningkatan mutu prasarana dan sarana transportasi kebanyakan bertujuan mengurangi biaya ini. Biaya operasi kendaraan antara lain meliputi penggunaan bahan bakar, pelumas, biaya penggantian (misalnya ban), biaya perawatan kendaraan dan upah atau gaji sopir.

\section{Gambaran Umum Lokasi Penelitian}

Kota Pontianak merupakan Ibukota Provinsi Kalimantan Barat. Kota Pontianak berada di wilayah yang dilalui oleh garis khatulistiwa, yaitu terletak di $0^{\circ} 02$ '24" Lintang Utara sampai dengan 005'37" Lintang Selatan, dan 109 6'25" Bujur Timur sampai dengan 109 23'01" Bujur Timur. Ketinggian Kota Pontianak berkisar antara 0,10 sampai 1,50 meter di atas permukaan laut (mdpl). 


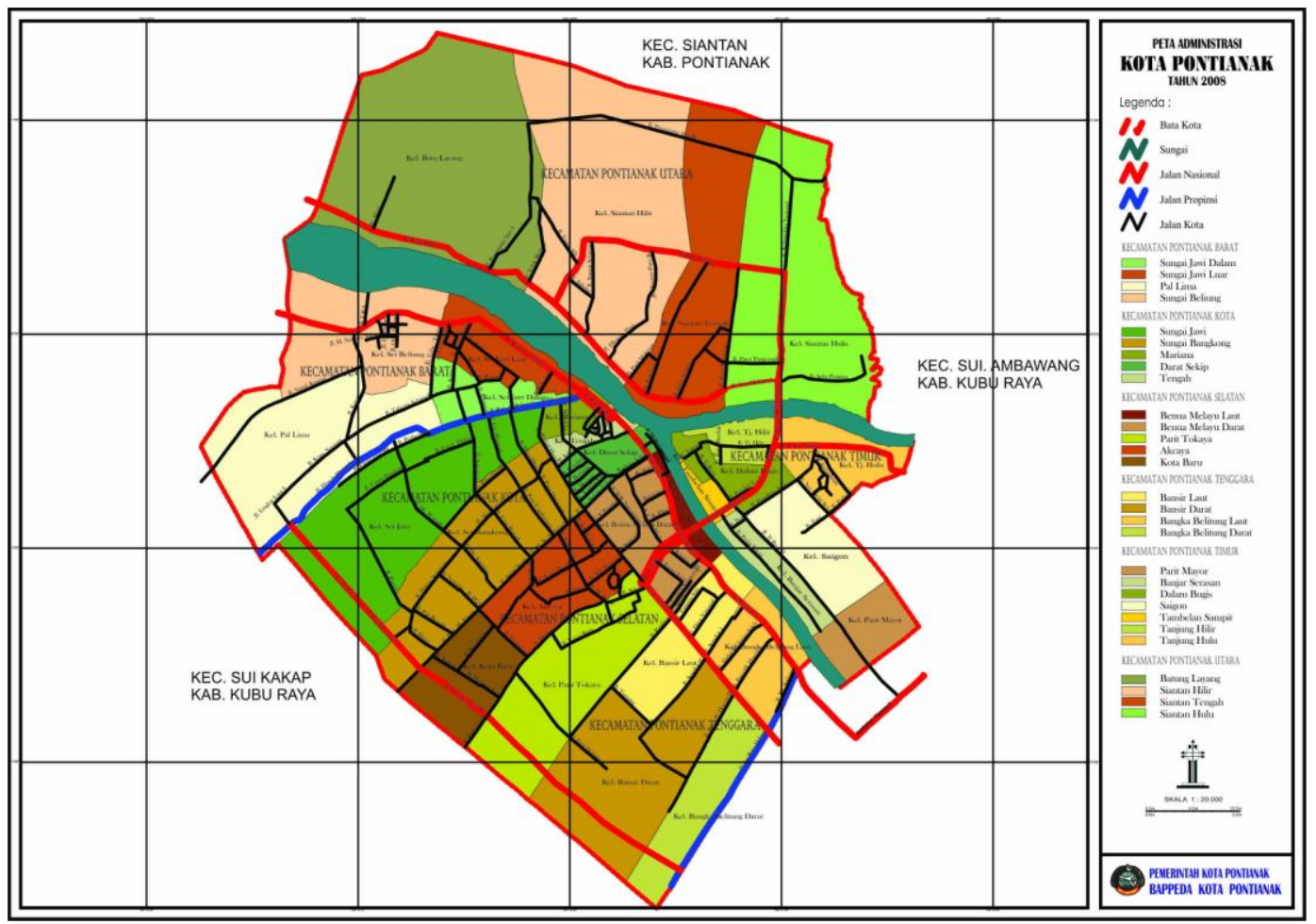

Gambar 2. Peta Administrasi Kota Pontianak

Sumber: bappeda.pontianakkota.go.id, 2017

Luas wilayah Kota Pontianak mencapai 107,82 km², memiliki 6 kecamatan, 29 kelurahan, 579 Rukun Warga (RW) dan 2.572 Rukun Tetangga. Kecamatan di Kota Pontianak yang mempunyai wilayah terluas adalah Kecamatan Pontianak Utara (34,52\%), diikuti oleh Kecamatan Pontianak Barat (15,25\%), Kecamatan Pontianak Kota (14,39\%), Kecamatan Pontianak Tenggara (13,75 \%), Kecamatan Pontianak Selatan $(13,49 \%)$ dan Kecamatan Pontianak Timur $(8,14 \%)$.

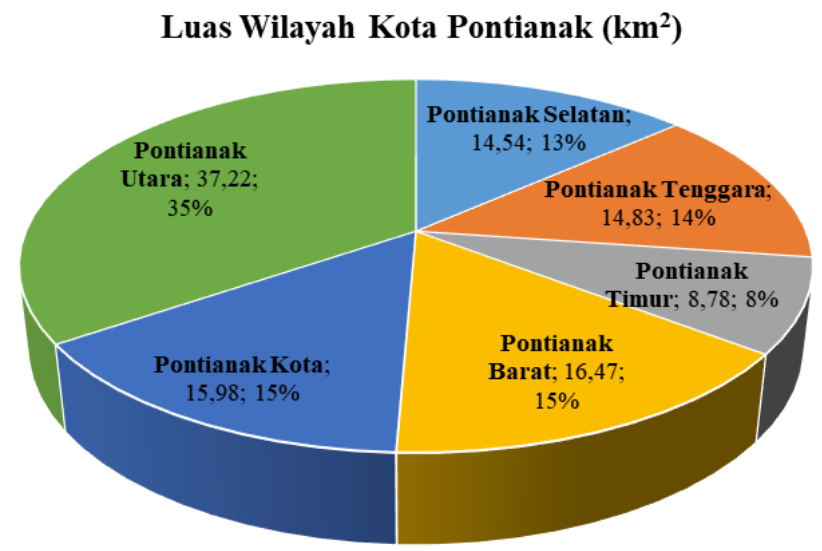

Gambar 3. Luas Wilayah Kota Pontianak Menurut Kecamatan, 2017

Sumber: BPS Kota Pontianak, 2017 


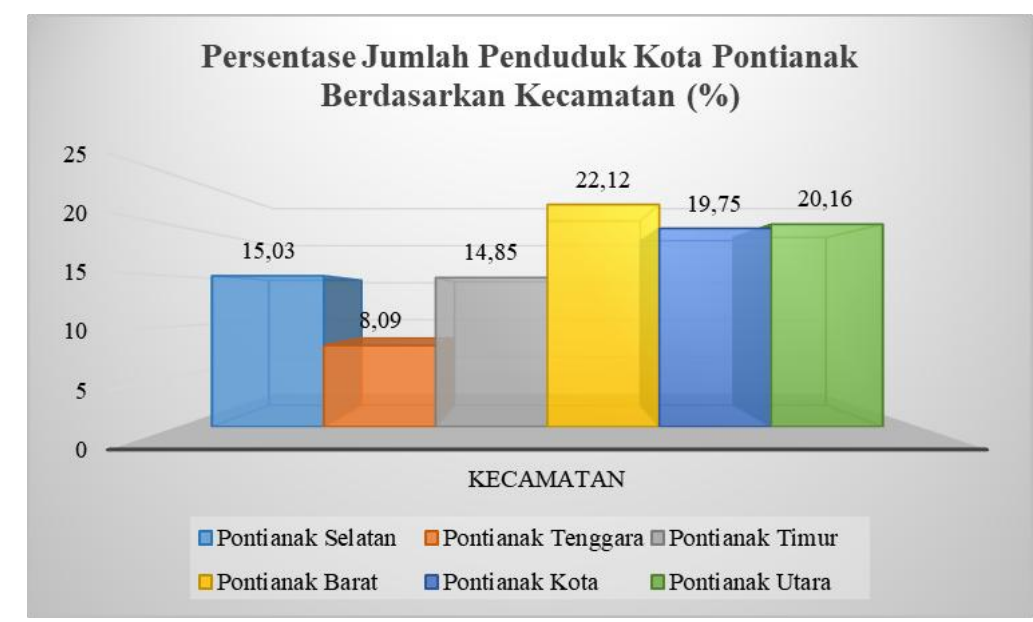

Gambar 4. Persentase Jumlah Penduduk Kota Pontianak Menurut Kecamatan Tahun 2016 Sumber: BPS Kota Pontianak, 2017

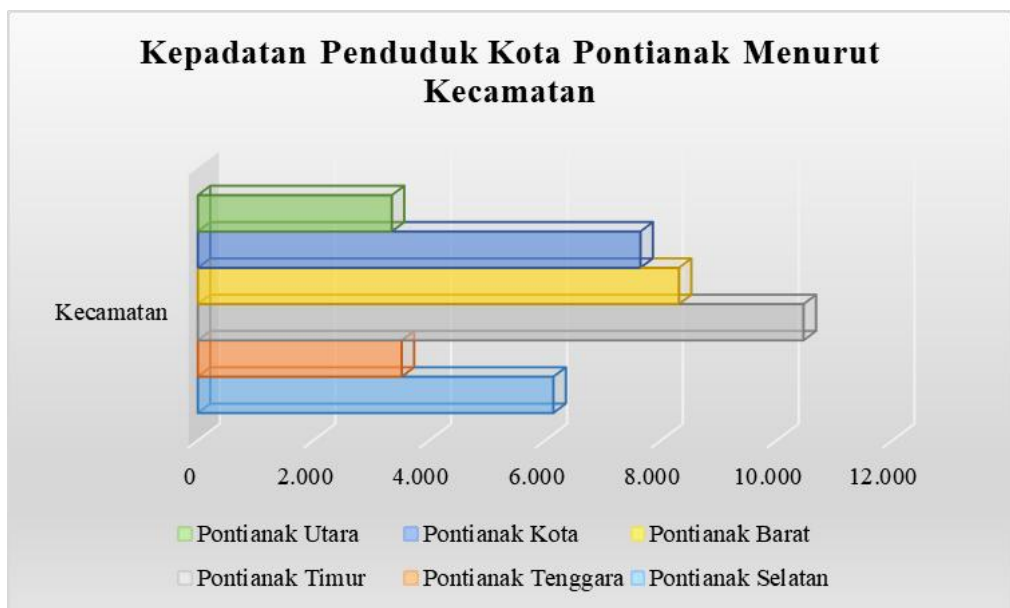

Gambar 5. Kepadatan Penduduk Kota Pontianak Menurut Kecamatan Tahun 2016 Sumber: BPS Kota Pontianak, 2017

Gambar di atas menunjukkan bahwa kepadatan penduduk di Kecamatan Pontianak Utara adalah yang paling rendah di Kota Pontianak, yaitu $3.312 \mathrm{jiwa} / \mathrm{km}^{2}$. Kecamatan Pontianak Timur merupakan kecamatan yang memiliki kepadatan penduduk tertinggi di atas $10.000 \mathrm{jiwa} / \mathrm{km}^{2}$, diikuti oleh Kecamatan Pontianak Barat, Kecamatan Pontianak Kota, Kecamatan Pontianak Selatan dan Kecamatan Pontianak Tenggara. Gambaran di atas menjelaskan bahwa walaupun Kecamatan Pontianak Utara memiliki jumlah penduduk kedua terbesar di Kota Pontianak, tidak berarti memiliki kepadatan terbesar, hal ini dikarenakan luasnya wilayah yang dimiliki oleh kecamatan ini dibandingkan dengan wilayah kecamatan lainnya.

Kecamatan Pontianak Utara terletak di bagian sebelah utara Sungai Kapuas di Kota Pontianak. Batas-batas kecamatan Pontianak Utara adalah:

- Sebelah Utara : Berbatasan dengan Desa Wajok Hulu, Kecamatan Siantan, Kabupaten Kubu Raya

- Sebelah Selatan : Berbatasan dengan Sungai Kapuas

- Sebelah Timur : Berbatasan dengan Desa Mega Timur, Kecamatan Siantan, Kabupaten Kubu Raya, dan

- Sebelah Barat : Berbatasan dengan Desa Wajok Hulu, Kecamatan Siantan, Kabupaten Kubu Raya 
Luas wilayah Kecamatan Pontianak Utara sebesar 39,97 $\mathrm{km}^{2}$ atau 3.997 ha yang terdiri dari empat kelurahan, yaitu:

1) Kelurahan Batu Layang

2) Kelurahan Siantan Hilir

3) Kelurahan Siantan Tengah

4) Kelurahan Siantan Hulu

Kelurahan yang paling luas adalah kelurahan Siantan Tengah, yaitu $13,70 \mathrm{~km}^{2}$ atau $34,27 \%$ dari jumlah luas kecamatan. Kelurahan yang paling kecil adalah Kelurahan Siantan Hilir yaitu $7,87 \mathrm{~km}^{2}$ atau sebesar $19,69 \%$ dari jumlah luas Kecamatan Pontianak Utara.

Jumlah Penduduk Kecamatan Pontianak Utara tahun 2016 sebanyak 123.272 jiwa. Jumlah penduduk yang paling banyak adalah di Kelurahan Siantan Hulu, yaitu 40.406 jiwa atau sebesar $32,77 \%$ dari jumlah penduduk Kecamatan Pontianak Utara. Jumlah penduduk paling sedikit yaitu di Kelurahan Batu Layang yaitu 20.743 atau sebesar 16,83\% dari total jumlah penduduk di Kecamatan Pontianak Utara. Kepadatan penduduk yang paling padat berada di Kelurahan Siantan Hulu yaitu dengan Kepadatan 4.392 jiwa $/ \mathrm{km}^{2}$, lebih padat bila dibandingkan kepadatan penduduk Kecamatan Pontianak Utara, yaitu dengan kepadatan $3.312 \mathrm{jiwa} / \mathrm{km}^{2}$.

Tabel 1. Luas Wilayah, Jumlah Penduduk, dan Kepadatan di Kecamatan Pontianak Utara Menurut Kelurahan, 2017

\begin{tabular}{|c|c|c|c|}
\hline Kecamatan & $\begin{array}{l}\text { Luas } \\
\left(\mathbf{k m}^{2}\right)\end{array}$ & $\begin{array}{l}\text { Jumlah } \\
\text { Penduduk }\end{array}$ & $\begin{array}{l}\text { Kepadatan } \\
\text { (Jiwa/km2) }\end{array}$ \\
\hline Batu Layang & 6.45 & 20.743 & 3.216 \\
\hline Siantan Hilir & 7.87 & 29.443 & 3.742 \\
\hline Siantan Tengah & 13.7 & 32.680 & 2.386 \\
\hline Siantan Hulu & 9.2 & 40.406 & 4.392 \\
\hline & 37.22 & 123.272 & 3.312 \\
\hline
\end{tabular}

Sumber: BPS Kota Pontianak, 2017

Tabel 2. Jumlah Rukun Warga, Rukun Tetangga, dan Kepala Keluarga di Kecamatan Pontianak Utara Menurut Kelurahan, 2017

\begin{tabular}{lrrrr}
\hline Kecamatan & RW & & RT & \multicolumn{2}{c}{ KK } \\
\hline Batu Layang & 20 & 90 & 4.995 \\
\hline Siantan Hilir & 40 & 151 & 8.791 \\
\hline Siantan Tengah & 33 & 132 & 9.501 \\
\hline Siantan Hulu & 38 & 158 & 8.191 \\
\hline & Jumlah & 131 & 531 & 31.478 \\
\hline
\end{tabular}

Sumber: BPS Kota Pontianak, 2017

Tabel 3. Sebaran Fasilitas Ekonomi Kecamatan Pontianak Utara, 2017

\begin{tabular}{lrrrrrrr}
\hline Kecamatan & $\begin{array}{l}\text { Pasar } \\
\text { Umum }\end{array}$ & Supermarket & Pegaadaian & Bank & Asuransi & MiniMarket \\
\hline Batu Layang & 0 & 0 & 1 & 0 & 0 & 0 \\
\hline Siantan Hilir & 0 & 0 & 0 & 2 & 0 & 3 \\
\hline Siantan Tengah & 2 & 2 & 1 & 7 & 0 & 0 \\
\hline Siantan Hulu & 0 & 0 & 2 & 2 & 0 & 11 \\
\hline \multicolumn{1}{c}{ Jumlah } & 2 & 2 & 4 & 11 & 0 & 14 \\
\hline
\end{tabular}

Sumber: BPS Kota Pontianak, 2017 
Tabel 4. Sebaran Fasilitas Pendidikan Kecamatan Pontianak Utara, 2017

\begin{tabular}{lrrrrrrrrrrrr}
\hline \multicolumn{1}{c}{ Kecamatan } & SDN & SDS & SMPN & SMPS & SMAN & SMAS & SMKN & SMKS & RA & MIS & Mts & MAS \\
\hline Batu Layang & 4 & 0 & 2 & 2 & 1 & 1 & 0 & 0 & 1 & 2 & 1 & 0 \\
\hline Siantan Hilir & 10 & 2 & 3 & 1 & 0 & 0 & 1 & 2 & 3 & 3 & 2 & 1 \\
\hline Siantan Tengah & 5 & 5 & 0 & 5 & 0 & 4 & 1 & 1 & 1 & 3 & 2 & 1 \\
\hline Siantan Hulu & 12 & 0 & 2 & 2 & 0 & 0 & 1 & 0 & 1 & 2 & 3 & 2 \\
\hline \multicolumn{1}{r}{ Jumlah } & 31 & 7 & 6 & 10 & 1 & 5 & 3 & 3 & 6 & 10 & 8 & 4
\end{tabular}

Sumber: BPS Kota Pontianak, 2017

Tabel 5. Sebaran Fasilitas Keagamaan Kecamatan Pontianak Utara, 2017

\begin{tabular}{lrrrrrr}
\hline \multicolumn{1}{c}{ Kecamatan } & Masjid & Surau/Langgar & Gereja & Vihara & Kelenteng & Pura \\
\hline Batu Layang & 13 & 14 & 3 & 1 & 2 & 1 \\
\hline Siantan Hilir & 13 & 30 & 2 & 2 & 3 & 0 \\
\hline Siantan Tengah & 6 & 11 & 3 & 1 & 4 & 2 \\
\hline Siantan Hulu & 19 & 30 & 5 & 2 & 4 & 0 \\
\hline \multicolumn{1}{c}{ Jumlah } & 51 & 85 & 13 & 6 & 13 & 3 \\
\hline
\end{tabular}

Sumber: BPS Kota Pontianak, 2017

Tabel 6. Sebaran Fasilitas Kesehatan Kecamatan Pontianak Utara, 2017

\begin{tabular}{|c|c|c|c|c|c|c|c|c|c|c|c|c|}
\hline \multirow[t]{2}{*}{ Kecamatan } & \multirow[t]{2}{*}{ Puskesmas } & \multirow{2}{*}{$\begin{array}{l}\text { Puskesmas } \\
\text { Pembantu }\end{array}$} & \multirow{2}{*}{$\begin{array}{l}\text { RSU/RS } \\
\text { Bersalin }\end{array}$} & \multirow[t]{2}{*}{ Poliklinik } & \multirow[t]{2}{*}{ BKIA } & \multirow[t]{2}{*}{ Apotik } & \multicolumn{3}{|c|}{ Tempat Praktek } & \multirow[t]{2}{*}{ PPKBD } & \multirow[t]{2}{*}{ Posyandu } & \multirow[t]{2}{*}{ BKB } \\
\hline & & & & & & & Dokter & Bidan & Sinshe & & & \\
\hline Batu Layang & 1 & 1 & 0 & 0 & 0 & 0 & 0 & 1 & 0 & 1 & 13 & 0 \\
\hline Siantan Hilir & 1 & 1 & 0 & 1 & 0 & 1 & 4 & 1 & 0 & 1 & 23 & 1 \\
\hline Siantan Tengah & 1 & 1 & 2 & 0 & 0 & 5 & 10 & 1 & 0 & 1 & 14 & 2 \\
\hline Siantan Hulu & 2 & 1 & 0 & 0 & 0 & 2 & 2 & 4 & 0 & 1 & 31 & 1 \\
\hline Jumlah & 5 & 4 & 2 & 1 & 0 & 8 & 16 & 7 & 0 & 4 & 81 & 4 \\
\hline
\end{tabular}

Sumber: BPS Kota Pontianak, 2017

Tabel di atas menjelaskan sebaran fasilitas pelayanan publik yang terdapat di Kecamatan Pontianak Utara. Terlihat bahwa sebaran fasilitas pelayanan ekonomi di wilayah ini belum tersebar merata, khususnya untuk pasar umum dan supermarket. Namun fasilitas lainnya terlihat sudah cukup merata di semua wilayah kelurahan untuk semua tingkatan dan hierarki pelayanan publik.

\section{Metode Penelitian}

Tulisan ini merupakan bagian dari penelitian yang dilakukan penulis tentang Pengaruh Sebaran Lokasi dan Perencanaan Bangunan Gedung Kantor Pelayanan Publik Terhadap Pola Penggunaan Energi Bangunan dan Masyarakat di Kota Pontianak. Kondisi Kecamatan Pontianak Utara yang terletak terpisah di bagian utara kota dengan akses pencapaian menuju pusat kota dan kecamatan lainnya melalui Jembatan Kapuas, Jembatan Landak dan kapal penyeberangan menarik untuk ditelaah lebih lanjut. Sebagai bagian dari penelitian yang dilakukan, maka metode penelitian dalam penulisan ini merujuk kepada salah satu metode penelitian yang dilakukan, yaitu menggunakan metode kualitatif deskriptif (Purnomo \& Wulandari, 2017).

Teknik pengumpulan data yang digunakan melalui dua cara, yaitu pengumpulan data primer dan pengumpulan data sekunder. Penjelasan tentang teknik pengumpulan data yang digunakan dijelaskan di bawah ini: 
a) Pengumpulan data sekunder diperoleh dari kajian literatur yang terkait sebaran lokasi bangunan kantor pelayanan publik, salah satu sumber yang digunakan adalah data dari Badan Pusat Statistik Kota Pontianak.

b) Pengumpulan data primer diperoleh dengan menggunakan kuesioner kepada masyarakat dan kantor pelayanan publik. Kuesioner digunakan untuk mengetahui informasi pengaruh sebaran lokasi.

Pengambilan sampel dalam penelitian ini dilakukan dengan menggunakan rumus Slovin. Jumlah sampel yang diambil dari data jumlah penduduk di Kota Pontianak dengan taraf signifikansi $(\alpha)$ sebesar 5\%. Sampel di ambil secara proporsional sesuai dengan jumlah Kepala Keluarga (KK) yang ada di masing-masing kelurahan. Sampel yang diperoleh untuk wilayah Kecamatan Pontianak Utara adalah sebagai berikut:

Tabel 7. Jumlah KK dan Jumlah Sampel di Kecamatan Pontianak Utara Menurut Kelurahan

\begin{tabular}{lrr}
\hline \multicolumn{1}{c}{ Kelurahan dan Kecamatan } & Jumlah KK & \multicolumn{1}{c}{ Sampel } \\
\hline Batu Layang & 4.861 & 11 \\
\hline Siantan Hilir & 9.136 & 21 \\
\hline Siantan Tengah & 10.260 & 24 \\
\hline Siantan Hulu & 8.167 & 19 \\
\hline Pontianak Utara & $\mathbf{3 2 . 4 2 4}$ & $\mathbf{7 5}$ \\
\hline
\end{tabular}

Sumber: Purnomo \& Wulandari, 2017

Sampel penelitian yang diperoleh di Kecamatan Pontianak Utara berjumlah 75 jiwa, dengan sebaran di masing-masing kelurahan sebagaimana ter gambarkan dalam Tabel 3. Kelurahan Siantan Tengah memiliki sampel terbesar (24 jiwa) dikarenakan memiliki jumlah KK terbesar, sedangkan Kelurahan Batu Layang memiliki sampel terkecil dikarenakan memiliki jumlah KK paling kecil.

\section{Hasil dan Pembahasan}

\section{Karakteristik Responden}

Hasil penelitian berdasarkan kuesioner yang disebarkan kepada 75 responden yang berada di wilayah Kecamatan Pontianak Utara memperlihatkan karakteristik responden mayoritas adalah perempuan, yaitu sebanyak $75 \%$ dari total responden. Mayoritas responden memiliki tingkat pendidikan SLTA $(33,33 \%)$, SLTP $(26,67)$, SD (24\%), tidak bersekolah (10,67\%). Sedangkan 5,33\% sisanya memiliki tingkat pendidikan diploma dan sarjana.

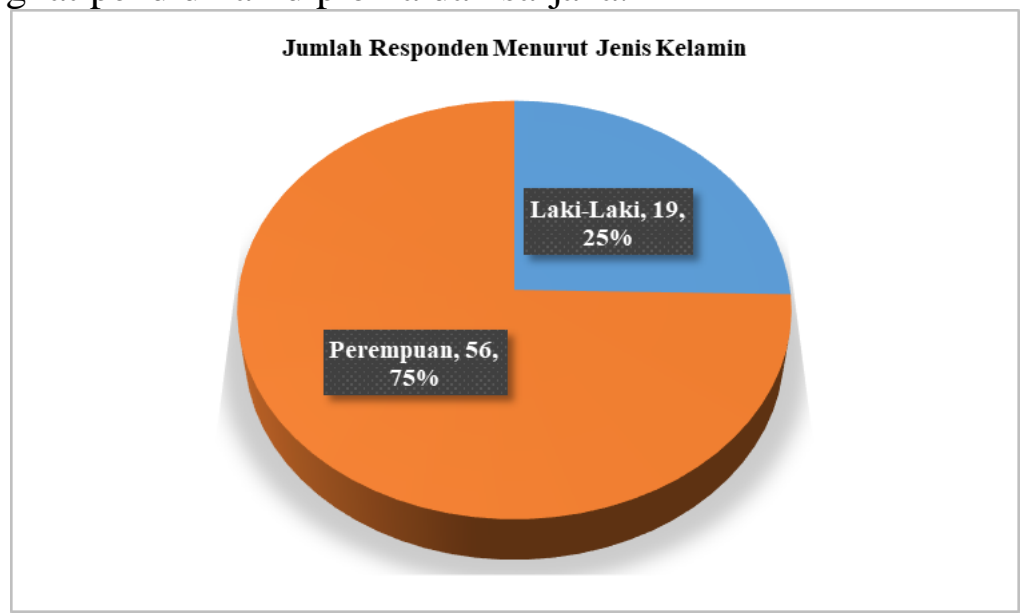

Gambar 6. Jumlah Responden menurut Jenis Kelamin Sumber: Analisis, 2017 


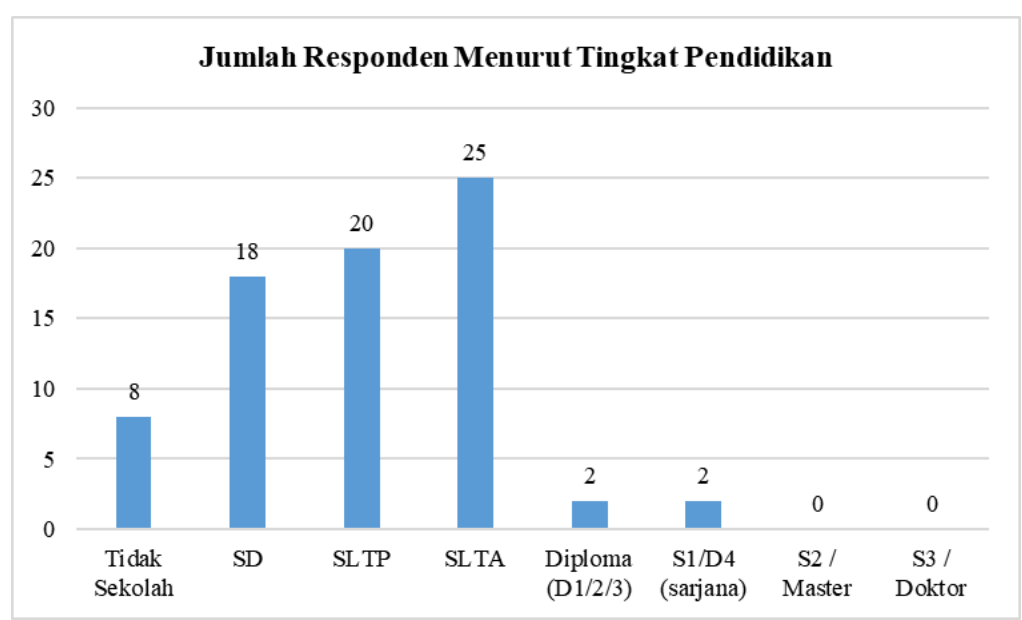

Gambar 7. Jumlah Responden menurut Tingkat Pendidikan

Sumber: Analisis, 2017

Karakteristik responden lainnya ditunjukkan berdasarkan kelompok usia, pekerjaan dan jumlah penghasilan. Sebagaimana ter gambarkan dalam Gambar 7, kelompok usia tersebar hampir merata di semua kelompok usia produktif dengan jumlah responden terbanyak di kelompok usia 30-34 tahun, yaitu sebanyak 18 responden atau $24 \%$ dari total jumlah responden. Selanjutnya Gambar 8 memperlihatkan karakteristik responden menurut Pekerjaan. Terlihat bahwa $40 \%$ responden adalah ibu rumah tangga, diikuti oleh wiraswasta sebanyak $24 \%$, karyawan swasta $13,33 \%$, dan sisanya adalah pelajar, buruh/tukang, tidak bekerja, dan pegawai negeri sipil .Gambar 9 menggambarkan bahwa rata-rata penghasilan responden berada di antara Rp.0 s.d. Rp. 2.600.000. Hal ini ditunjukkan oleh sebanyak $84 \%$ responden berpenghasilan pada rentang penghasilan tersebut, sedangkan $14,67 \%$ memiliki penghasilan antara Rp. 2.600 .000 s.d. Rp. 5.200.000, dan hanya 1 responden yang memiliki penghasilan di antara Rp.5.200.000 s.d. 7.800.000.

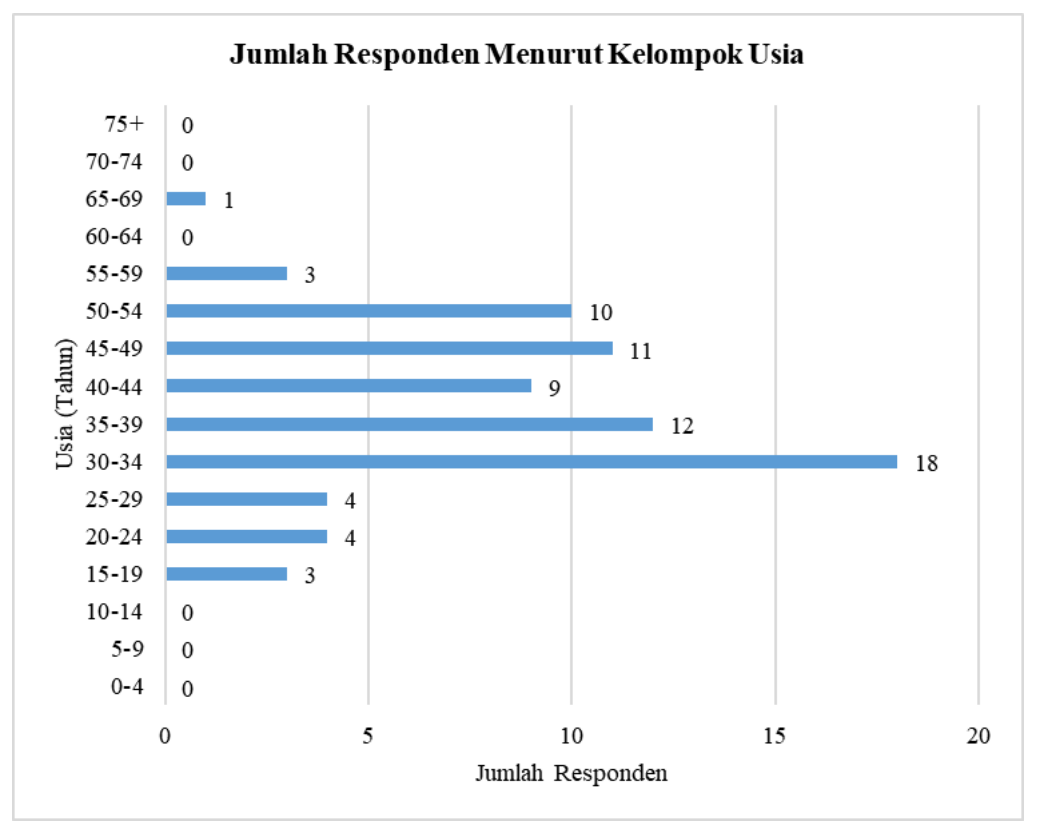

Gambar 8. Jumlah Responden menurut Kelompok Usia

Sumber: Analisis, 2017 


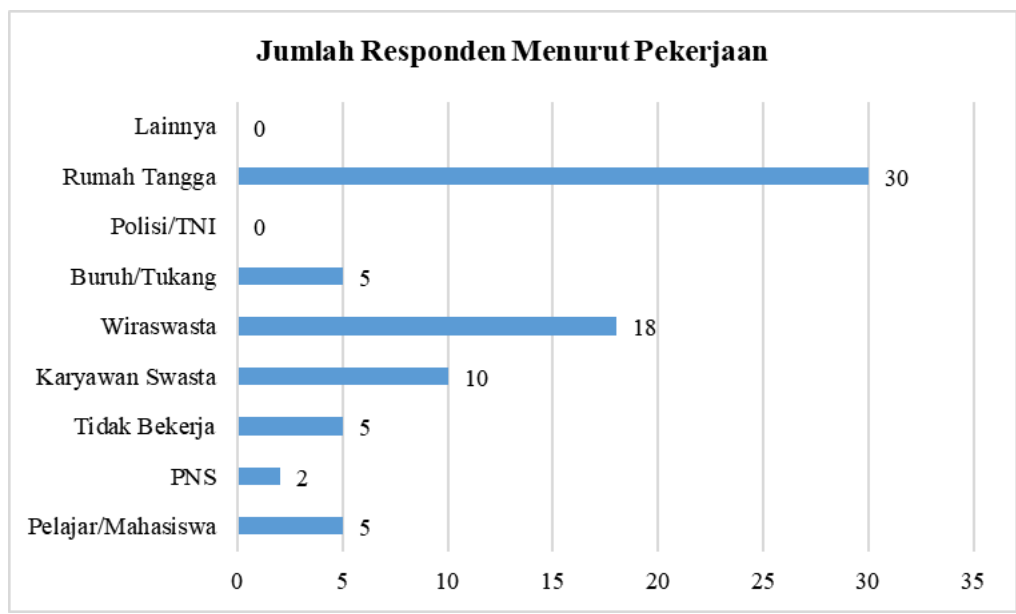

Gambar 9. Jumlah Responden menurut Pekerjaan

Sumber: Analisis, 2017

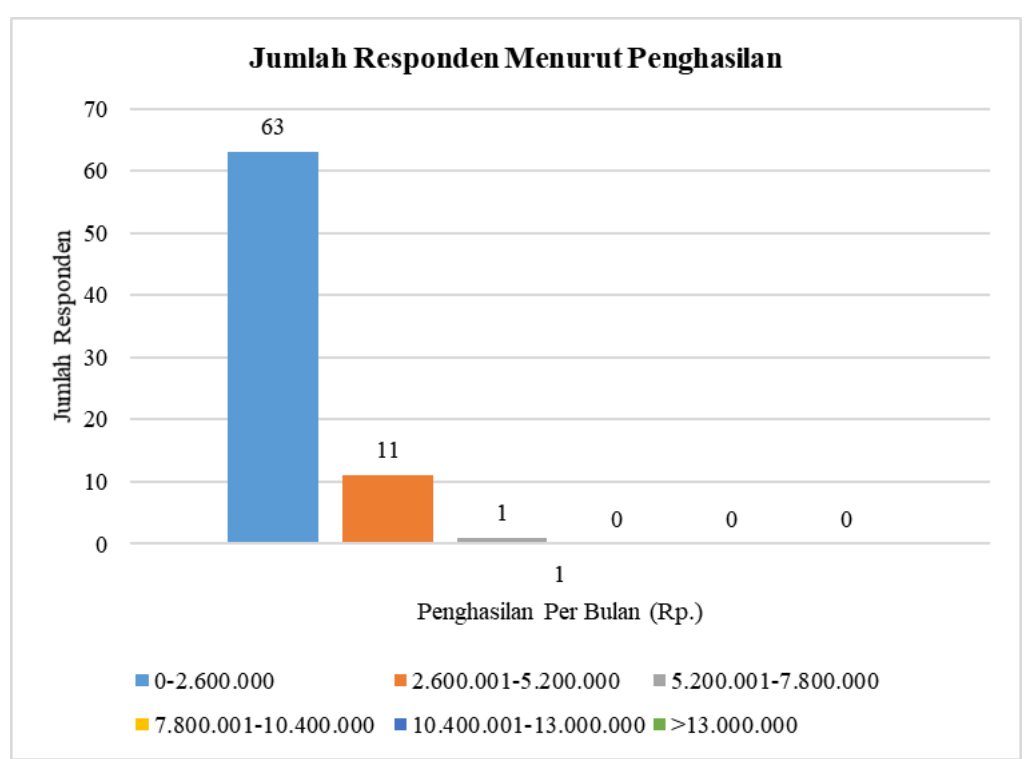

Gambar 10. Jumlah Responden menurut Penghasilan

Sumber: Analisis, 2017

Karakteristik masyarakat di Kecamatan Pontianak Utara lainnya berdasarkan hasil penelitian juga menunjukkan bahwa sebanyak $81 \%$ KK yang ada sudah memiliki atau menempati rumah milik pribadi, sedangkan 14,67\% menumpang, dan 4\% menempati rumah sewa atau kontrak. Sebagaimana kepemilikan rumah, kepemilikan kendaraan pribadi juga didominasi oleh kepemilikan sepeda motor pribadi, sepeda, dan mobil (lihat Gambar 11). Hanya kurang dari 3\% responden yang tidak memiliki kendaraan pribadi.

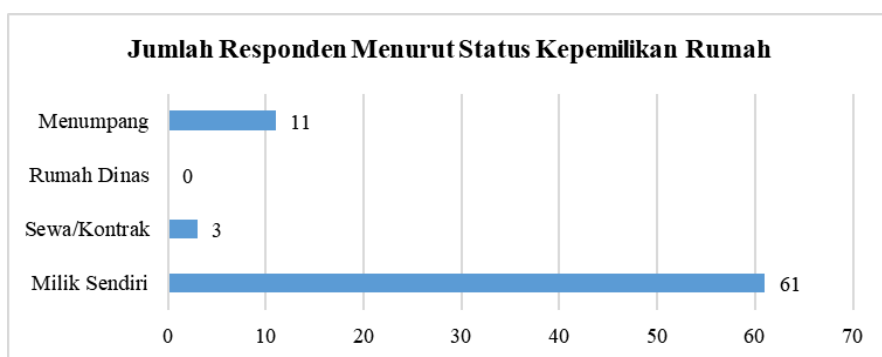

Gambar 11. Jumlah Responden menurut Kepemilikan Rumah Sumber: Analisis, 2017 


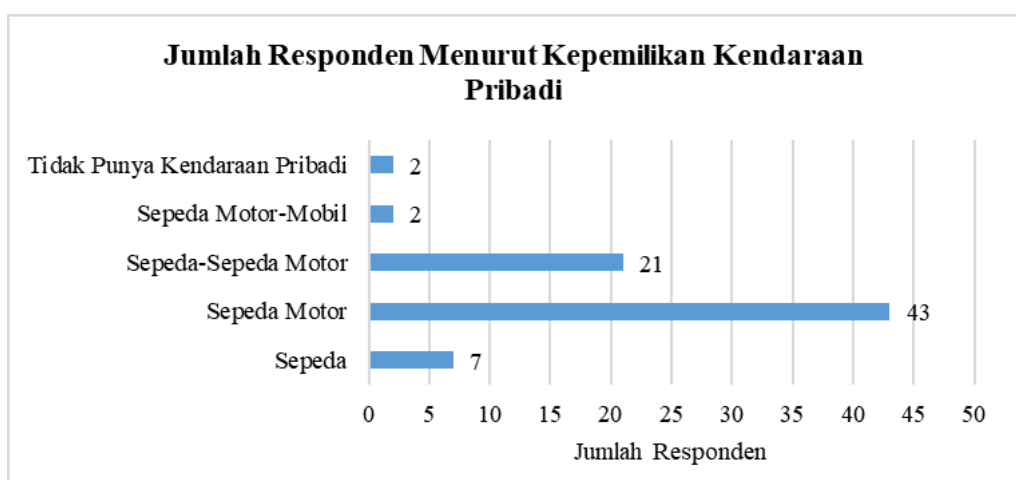

Gambar 12. Jumlah Responden menurut Kepemilikan Kendaraan

Sumber: Analisis, 2017

Sepeda motor pribadi juga menjadi kendaraan yang paling sering digunakan oleh masyarakat di Kecamatan Pontianak Utara di bandingkan dengan moda lainnya. Hal ini diperlihatkan dalam Gambar 12. Selain kendaraan pribadi, masyarakat di Kecamatan Pontianak Utara juga masih ada yang menggunakan kendaraan umum, yaitu Oplet/Angkot. Kombinasi pemilihan moda kendaraan antara kendaraan pribadi dan kendaraan umum serta jalan kaki masih dijumpai di Kecamatan Pontianak Utara.

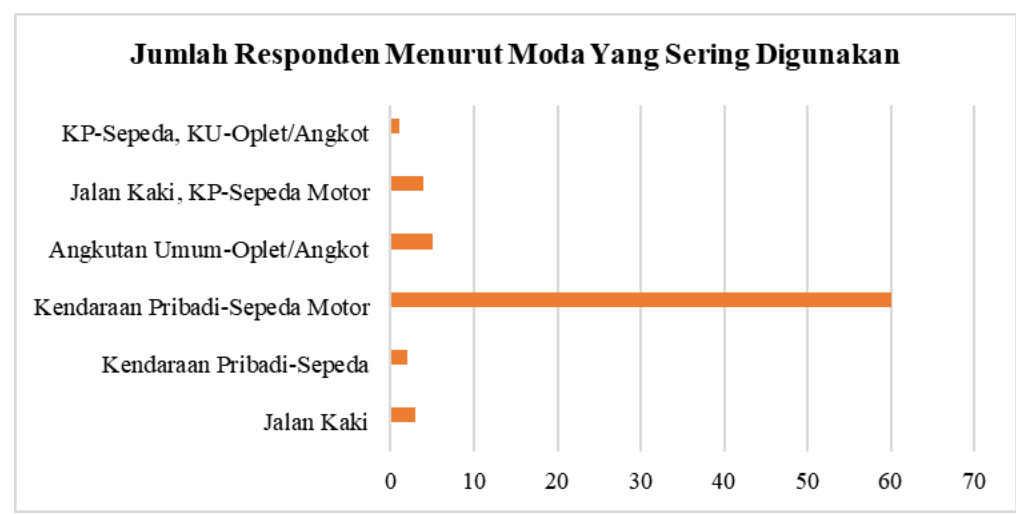

Gambar 13. Jumlah Responden menurut Moda Kendaraan yang Sering Digunakan Sumber: Analisis, 2017

\section{Sebaran dan Pilihan Fasilitas Pelayanan Publik}

Seperti yang telah diuraikan sebelumnya, tulisan ini mencoba menggambarkan pilihan masyarakat di Kecamatan Pontianak Utara terhadap fasilitas pelayanan publik yang ada dan tersebar di wilayah kecamatan maupun di wilayah Kota Pontianak. Berdasarkan karakteristik masyarakat Kecamatan Pontianak Utara terhadap beberapa fasilitas pelayanan publik, terlihat bahwa fasilitas pelayanan dasar sudah cukup terjangkau oleh warga masyarakat dan menjadi pilihan masyarakat. Sedangkan beberapa fasilitas pelayanan umum sudah terjangkau namun masyarakat di Kecamatan Pontianak Utara masih ada yang memilih fasilitas yang berada di luar wilayah tempat tinggalnya, sedangkan beberapa fasilitas umum terletak cukup jauh dan masyarakat Kecamatan Pontianak Utara tidak memiliki pilihan lain selain memilih fasilitas pelayanan umum tersebut. 


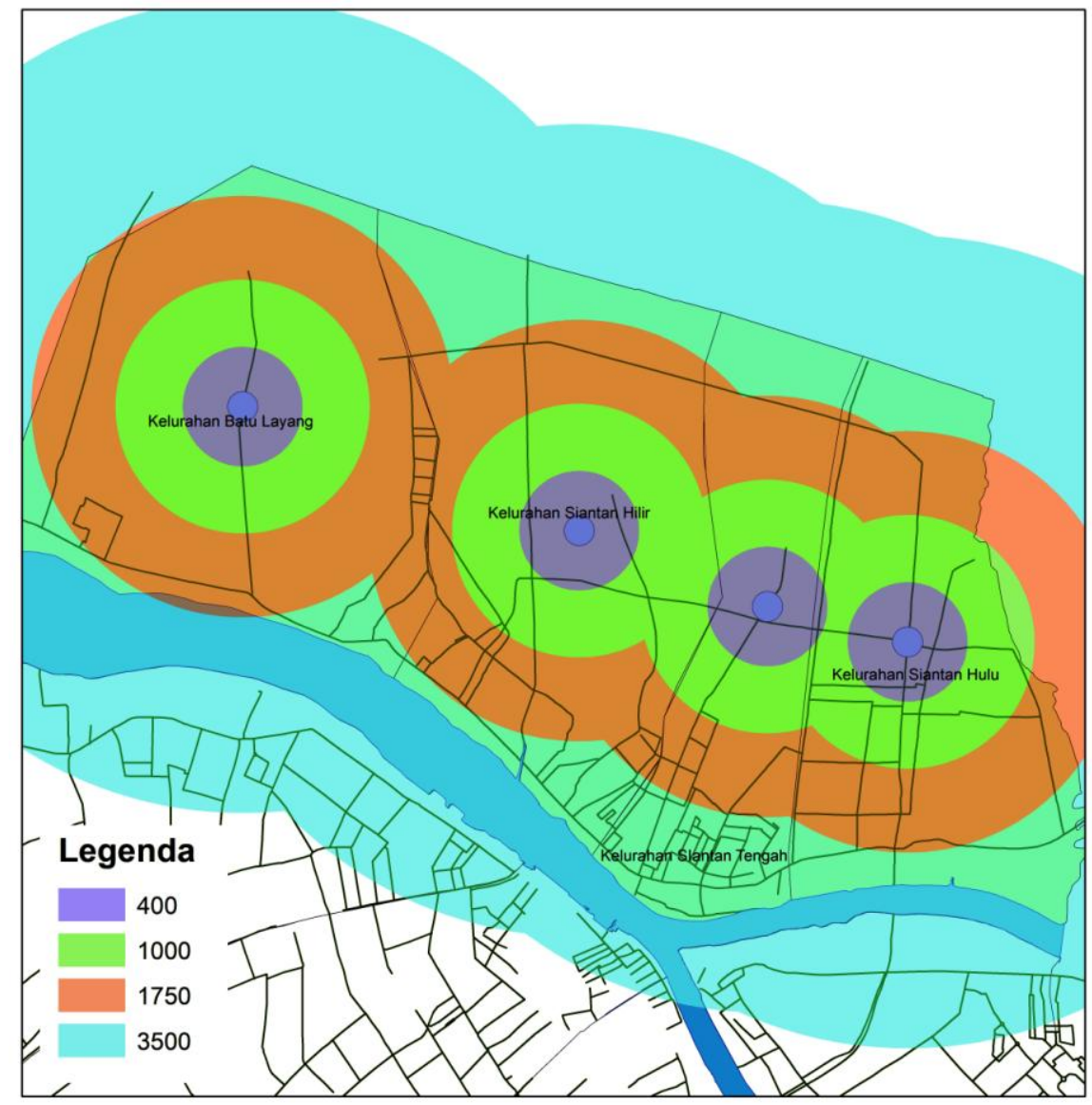

Gambar 14. Rentang Jarak di Kecamatan Pontianak Utara

Sumber: Analisis, 2017

Fasilitas Pendidikan dasar merupakan fasilitas pelayanan umum yang sangat terjangkau di wilayah Kecamatan Pontianak Utara. Karena wilayah ini memiliki sebaran sekolah dasar dan sekolah lanjutan tingkat pertama yang cukup terjangkau oleh masyarakat, yaitu berada di rentang jarak antara 0 s.d. $400 \mathrm{~m}$, serta sebagian kecil masyarakat menjangkau dengan jarak s.d $1.000 \mathrm{~m}$. Sehingga dari hasil sebaran ini terlihat pula bahwa untuk fasilitas pendidikan masyarakat memilih menyekolahkan anaknya di fasilitas pendidikan yang berada di sekitar lingkungan tempat tinggalnya.

Berbeda dengan fasilitas pendidikan dasar, fasilitas kesehatan di Kecamatan Pontianak Utara dirasakan oleh warga berada dalam rentang jarak sampai dengan 3.500 meter. Hal ini dikarenakan di Kecamatan Pontianak Utara sudah terdapat pusat kesehatan masyarakat namun masyarakat juga menginginkan adanya fasilitas kesehatan setingkat rumah sakit di wilayahnya. Rumah sakit terdekat di wilayah ini terletak di Kecamatan Pontianak Timur. Sehingga pilihan masyarakat akan fasilitas kesehatan terlihat mengikuti keberadaan sebaran fasilitas kesehatan, mulai yang dekat dengan tempat tinggalnya, yaitu klinik, praktik dokter atau bidan, dan puskesmas, hingga fasilitas kesehatan yang berada hingga jarak $3,5 \mathrm{~km}$ berupa rumah sakit. 


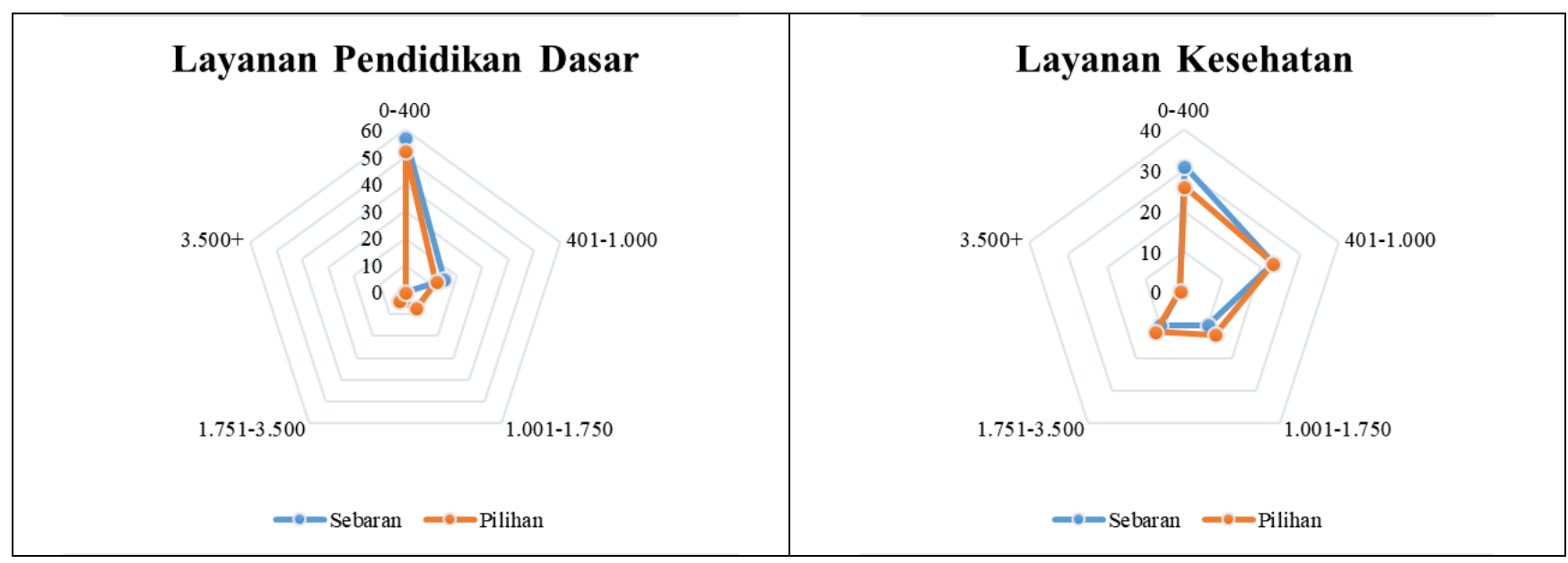

Gambar 15. Sebaran dan Pilihan Masyarakat Kecamatan Pontianak Utara Terhadap Fasilitas Pendidikan Dasar dan Kesehatan

Sumber: Analisis, 2017

Serupa dengan fasilitas layanan kesehatan, fasilitas layanan keagamaan seperti tempat ibadah di Kecamatan Pontianak Utara berada dalam rentang jarak sampai dengan 1.750 meter dari tempat tinggal penduduk. Sebaran dan pilihan masyarakat terhadap fasilitas pelayanan publik ini hampir merata untuk masing-masing jarak 0-400 meter, 401-1.000 meter dan 1.001-1.750 meter. Walaupun demikian pilihan jarak antara 1.001-1.750 merupakan pilihan yang paling banyak dipilih oleh warga masyarakat. Berbeda dengan fasilitas keagamaan, fasilitas layanan perniagaan dirasakan oleh masyarakat tersebar cukup jauh dari tempat tinggalnya. Sebagian besar masyarakat merasa bahwa sebaran terdekat untuk fasilitas ini berada pada jarak antara 401 s.d. 1.750 meter. Hal ini dimaklumi karena di Kecamatan Pontianak Utara terdapat pusat perniagaan yang terkonsentrasi di Pasar Siantan sedangkan sebaran tempat tinggal masyarakat berada cukup jauh dari pusat perniagaan tersebut.

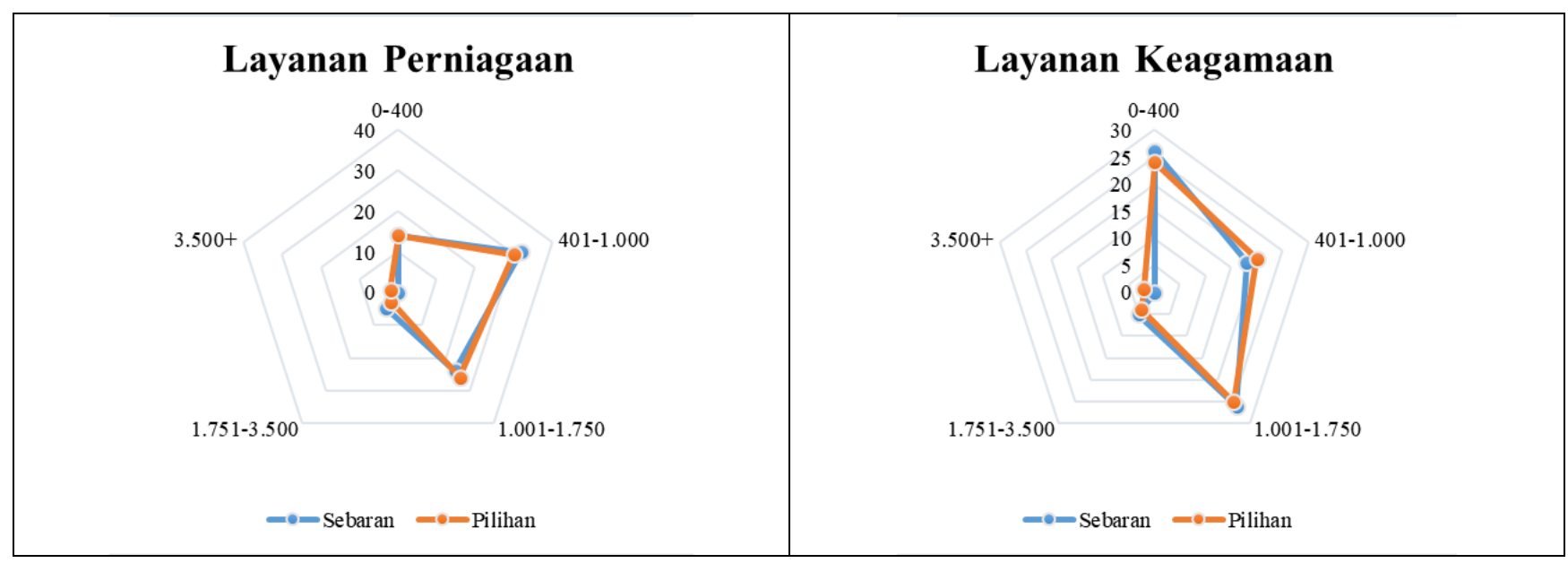

Gambar 16. Sebaran dan Pilihan Masyarakat Kecamatan Pontianak Utara Terhadap Fasilitas Peniagaan dan Keagamaan

Sumber: Analisis, 2017

Fasilitas pelayanan administrasi kependudukan di Kecamatan Pontianak Utara terdapat di masing-masing kantor kelurahan dan kantor kecamatan yang jaraknya sudah terjangkau dan cukup dekat dengan tempat tinggal penduduknya. Jarak yang ditempuh oleh masyarakat untuk mencapai Pusat Pelayanan Kecamatan berada dalam rentang jarak sampai dengan 1.750 meter. Namun untuk pelayanan administrasi di tingkat kota, jarak yang ditempuh oleh masyarakat sangat jauh, yaitu 
berada dalam rentang jarak lebih dari $3,5 \mathrm{~km}$. Hal ini disebabkan karena untuk urusan tersebut dilakukan masyarakat di Kantor Dinas Kependudukan dan Pencatatan Sipil yang berada di Kecamatan Pontianak Selatan. Jauhnya jarak pelayanan di tingkat kota yang dirasakan oleh masyarakat di Kecamatan Pontianak Utara juga dirasakan untuk fasilitas pelayanan di bidang administrasi perijinan, administrasi agraria dan administrasi keimigrasian, di mana lokasi sebaran kantor pelayanan publik ini berada di Kecamatan Pontianak Selatan.

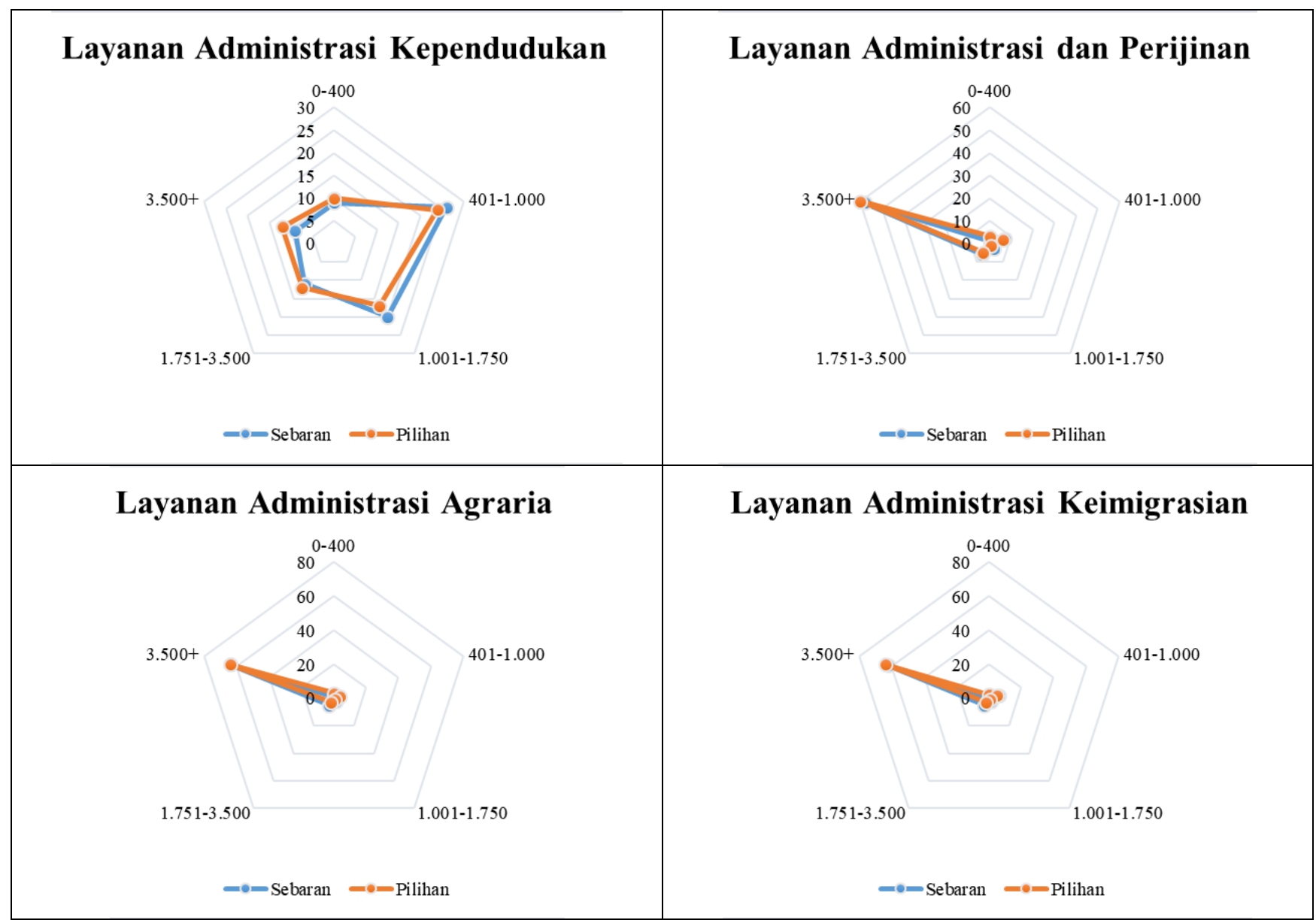

Gambar 17. Sebaran dan Pilihan Masyarakat Kecamatan Pontianak Utara Terhadap Fasilitas Administrasi Kependudukan, Perijinan, Agraria dan Keimigrasian

Sumber: Analisis, 2017

Fasilitas hiburan dan rekreasi di Kecamatan Pontianak Utara dirasakan oleh masyarakatnya sudah mencukupi dan merata untuk berbagai rentang jarak. Walaupun demikian fasilitas layanan berupa fasilitas hiburan dan rekreasi di Kecamatan Pontianak Utara ini cukup berbeda dengan fasilitas lainnya yang telah di bahas sebelumnya. Pilihan masyarakat terhadap rentang jarak sebaran fasilitas ini dirasakan cukup merata. Artinya masyarakat merasakan bahwa fasilitas dalam rentang jarak yang dekat cukup memenuhi kebutuhan mereka, namun fasilitas yang memiliki rentang jarak yang jauh juga menjadi tujuan dari masyarakat di wilayah ini. 


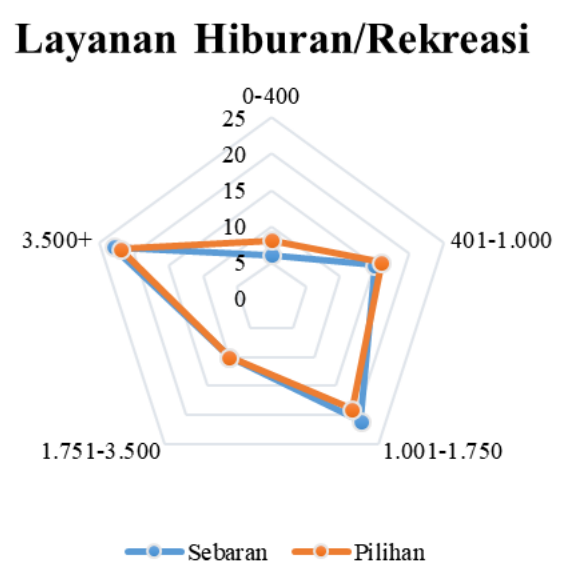

Gambar 18. Sebaran dan Pilihan Masyarakat Kecamatan Pontianak Utara Terhadap Fasilitas Hiburan dan Rekreasi

Sumber: Analisis, 2017

Sebaran dan pilihan masyarakat di Kecamatan Pontianak Utara terhadap fasilitas pelayanan publik paling banyak dipengaruhi oleh faktor jarak tempuh. Hampir semua pilihan fasilitas pelayanan publik dipengaruhi oleh jarak tempuh, kecuali untuk fasilitas pelayanan pendidikan dasar, pilihan masyarakat lebih banyak dipengaruhi oleh faktor kualitas pelayanan (lihat Gambar 18). Faktor jarak tempuh menjadi penting sebagai faktor yang mempengaruhi pilihan masyarakat terutama pada fasilitas perniagaan, fasilitas hiburan/rekreasi dan peribadatan. Hal ini dapat dijelaskan sebagai berikut:

- Jarak tempuh yang jauh namun menjadi pilihan khususnya untuk fasilitas perniagaan dan hiburan bagi masyarakat dikarenakan rentang jarak tempuh juga menjadi sarana masyarakat untuk melepaskan kejenuhan dengan menikmati pemandangan selama perjalanan.

- Faktor jarak tempuh dalam memilih fasilitas peribadatan oleh masyarakat dianggap penting karena melakukan perjalanan dengan rentang jarak yang makin jauh untuk aktivitas peribadatan sebanding dengan balasan yang akan mereka diterima menurut keyakinannya.

- Selain fasilitas perniagaan, hiburan, dan peribadatan, pertimbangan jarak tempuh oleh masyarakat untuk fasilitas pelayanan publik mempertimbangkan jarak terdekat dengan tempat tinggal.

Selain faktor jarak tempuh, faktor lain yang mempengaruhi masyarakat dalam memilih fasilitas layanan adalah faktor kualitas layanan. Fasilitas pendidikan dasar merupakan fasilitas yang dipilih dengan pertimbangan tertinggi untuk kualitas layanan. Hasil ini mengindikasikan bahwa kualitas pelayanan pendidikan dasar di wilayah ini memiliki kualitas yang cukup baik menurut masyarakat. Hal ini ditandai dengan dipilihnya fasilitas pelayanan publik yang sangat dekat tempat tinggal responden.

Pilihan yang cukup jauh untuk fasilitas administrasi dan perijinan, administrasi agraria, administrasi keimigrasian, dan administrasi kependudukan dikarenakan masyarakat tidak memiliki pilihan lain. Karena satu-satunya kantor untuk urusan tersebut terpusat di wilayah lainnya, di luar Kecamatan Pontianak Utara yang harus ditempuh oleh masyarakat dengan jarak lebih dari 3,5 km. Fasilitas pelayanan administrasi kependudukan terhadap masyarakat di Kota Pontianak tidak dilakukan secara terpusat, namun juga dilayani ditingkat kelurahan dan kecamatan sesuai dengan tingkat dan hierarki urusan kependudukan. 


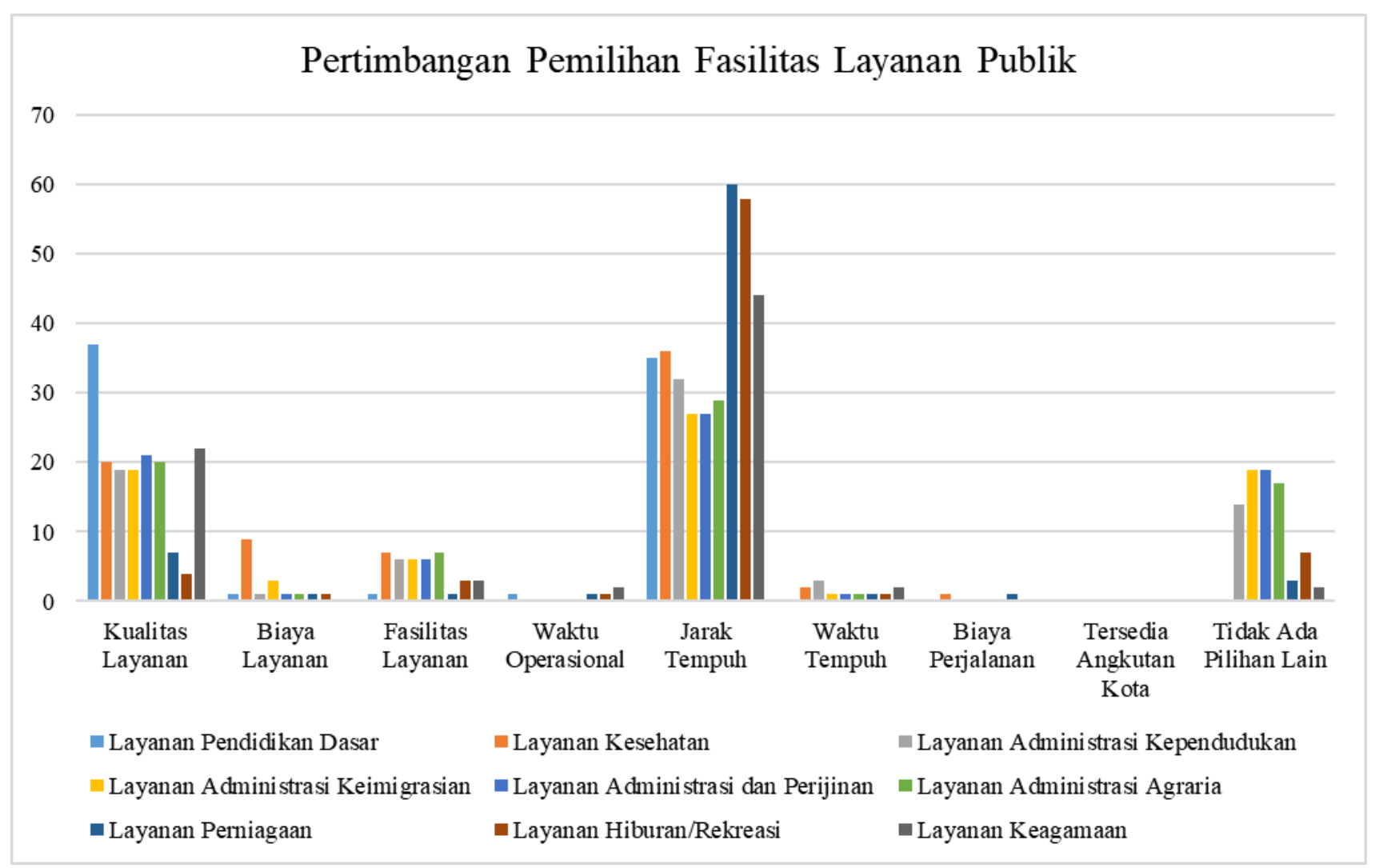

Gambar 19. Pertimbangan Pemilihan Fasilitas Pelayanan Publik

Sumber: Analisis, 2017

\section{Kesimpulan}

Dari hasil analisis statistik deskriptif di atas, dapat diambil beberapa kesimpulan, yaitu:

1. Di Kecamatan Pontianak Utara sudah tersebar fasilitas pelayanan publik dengan kualitas dan fasilitas layanan yang beragam.

2. Kualitas pelayanan pendidikan dasar dirasakan masyarakat sudah cukup baik dan berada dekat dengan wilayah tempat tinggalnya.

3. Masyarakat cenderung memilih fasilitas pelayanan publik yang memiliki jarak tempuh yang dekat dengan tempat tinggal, namun ada kecenderungan memilih fasilitas yang memiliki jarak tempuh relatif jauh untuk fasilitas perniagaan, hiburan, dan peribadatan.

4. Pertimbangan jarak tempuh dan kualitas layanan fasilitas pelayanan publik merupakan dua pertimbangan paling penting dalam pengambilan keputusan pemilihan fasilitas pelayanan publik oleh masyarakat, khususnya di Kecamatan Pontianak Utara.

5. Fasilitas yang diberikan, biaya layanan, waktu operasional, waktu tempuh, dan biaya perjalanan merupakan faktor yang mempengaruhi pengambilan keputusan pilihan fasilitas pelayanan publik dalam skala yang sangat kecil.

6. Pilihan masyarakat terhadap fasilitas pelayanan publik tidak dipengaruhi ada atau tidaknya angkutan kota di wilayah ini dikarenakan Sepeda motor merupakan moda kendaraan yang paling banyak digunakan oleh masyarakat di Kecamatan Pontianak Utara untuk bepergian dalam kehidupan sehari-harinya 


\section{Daftar Pustaka}

BPS Kota Pontianak. (2017). Kecamatan Pontianak Utara dalam Angka 2017. Pontianak: BPS Kota Pontianak.

BPS Kota Pontianak. (2017). Kota Pontianak dalam Angka 2017. Pontianak: BPS Kota Pontianak.

Nurmandi, A. (1999). Manajemen Perkotaan: Aktor, Organisasi, dan Pengelolaan Daerah Perkotaan di Indonesia . Yogyakarta: Lingkaran Bangsa.

Pemerintah Republik Indonesia. (2009). Undang Undang Republik Indonesia Nomor 25 Tahun 2009 tentang Pelayanan Publik.
Purnomo, Y., \& Wulandari, A. (2017). Pengaruh Sebaran Lokasi dan Perencanaan Bangunan Gedung Kantor Pelayanan Publik Terhadap Pola Penggunaan Energi Bangunan dan Masyarakat di Kota Pontianak. Universitas Tanjungpura. Pontianak: Tidak Dipublikasikan.

Tamin, O. Z. (2000). Perencanaan dan Pemodelan Transportasi. Bandung: Penerbit ITB.

Tarigan, R. (2006). Perencanaan Pembangunan Wilayah. Jakarta: PT. Bumi Aksara.

Warpani, S. (1990). Merencanakan Sistem Perangkutan. Bandung: ITB. 